\title{
The effect of certain dietary factors on the apparent absorption of magnesium by the rat
}

\author{
By JOYCE TOOTHILL \\ National Institute for Research in Dairying, Shinfield, Reading
}

(Received 18 Fune $1962-$ Revised $_{4}$ October 1962)

\begin{abstract}
Numerous workers have established a connexion between the metabolism of magnesium and various dietary factors. Thus Colby \& Frye $\left(195^{\mathrm{r}} b\right)$ working with young rats on a low-Mg, low-calcium diet observed reduction in blood $\mathrm{Mg}$ levels and increase in mortality rate when the casein content of the diet was increased from 24 to $50 \%$. Increased intake of Ca salts or of phosphates has been reported to affect $\mathrm{Mg}$ metabolism in rats (Tufts \& Greenberg, I937-8; Colby \& Frye, I95 I $a$; Hegsted, Vitale \& McGrath, 1956; O’Dell, Morris \& Regan, I960; McAleese \& Forbes, 1961), guinea-pigs
\end{abstract} (O’Dell et al. I960) and young dogs (Bunce, Chiemchaisri \& Phillips, I962) but no information is available from these experiments about the absorption of $\mathrm{Mg}$. The results of Heller \& Haddad (1936) indicate that the addition of calcium chloride to the drinking water of rats increased faecal $\mathrm{Mg}$, and recently Alcock \& MacIntyre (1960) found a decrease in absorption when rats receiving normal amounts of $\mathrm{Mg}$ and insufficient $\mathrm{Ca}$ had their $\mathrm{Ca}$ intake brought to normal. The experimental data of Malcolm (1905) are insufficient for any conclusions to be drawn concerning the effect of increased dietary $\mathrm{Ca}$ on $\mathrm{Mg}$ absorption in the dog. An increase in dietary phosphorus level reduced $\mathrm{Mg}$ absorption in the guinea-pig (O'Dell, Morris, Pickett \& Hogan, 1957) and chick (Nugara \& Edwards, I96I). Thus, although it is evident that $\mathrm{Ca}$ and phosphate impair $\mathrm{Mg}$ absorption in certain animals, the relative and combined effects of these two factors have not been studied to any great extent.

$\mathrm{Mg}$ absorption in healthy human subjects given a mixed diet low in protein and moderately low in $\mathrm{Ca}$ and supplemented with vegetables has been shown to be improved when protein replaced an equi-caloric amount of sugar or fat (McCance, Widdowson \& Lehmann, I942). The effect of increased dietary $\mathrm{Ca}$ is less clear; thus De \& Basu (1949) found that it impaired $\mathrm{Mg}$ absorption, but no definite effect is apparent from the results of Leichsenring, Norris \& Lamison (195I) either with increased dietary $\mathrm{Ca}$ alone, or with increased $\mathrm{Ca}$ and phosphate.

In the ruminant, Head \& Rook (1955, 1957) have suggested that the high levels of ammonia that occur in the rumen of cows grazing spring grass may interfere with $\mathrm{Mg}$ absorption from the small intestine or may reflect a reduction in the concentration there of amino acids, which could also result in poorer absorption.

In the experiments now reported the effect was studied of protein level, ammonium salts, $\mathrm{Ca}$ carbonate and sodium orthophosphate on the apparent absorption of $\mathrm{Mg}$. The main object was to study factors affecting the absorption of $\mathrm{Mg}$, and retention 
was determined in only one experiment. Rats were given diets containing about $20 \mathrm{mg} \mathrm{Mg} / \mathrm{r} 00 \mathrm{~g}$ diet, a level reported adequate for growth and maintenance of normal levels of blood $\mathrm{Mg}$ in young rats (Kunkel \& Pearson, 1948).

EXPERIMENTAL

\section{Diets and general technique}

The composition of, and content of some inorganic constituents in, the low- $\mathrm{Mg}$ basal diets and the experimental diets are given in Tables $I$ and 2. Male hooded Norwegian rats were housed individually in metabolic cages of the Hopkins type (Ackroyd \& Hopkins, I9I6) and fed to appetite. Diets were moistened with distilled water to prevent scattering. In addition, a vitamin mixture was given by pipette that provided a weekly dose of $\mathrm{I} \cdot 4 \mathrm{mg} \mathrm{DL}-\alpha$-tocopherol, 360 i.u. vitamin A and 26 i.u. vitamin D. Distilled water was given in glass bulbs. Faeces and urines were collected daily and, at the end of the collection period, the separator, urine container and glass funnel were rinsed with hot, about $0.6 \mathrm{~N}-\mathrm{HCl}$, and the rinsings added to the urine.

Table I. Percentage composition of the low-magnesium basal diets and their mean content of $M g$ and water

Component

Unextracted casein
Salt mixture
Margarine fat
Maize starch
Sugar
Choline chloride
Vitamin mixturet
Mg
Water

Basal diet no. 795 Basal diet no. 796

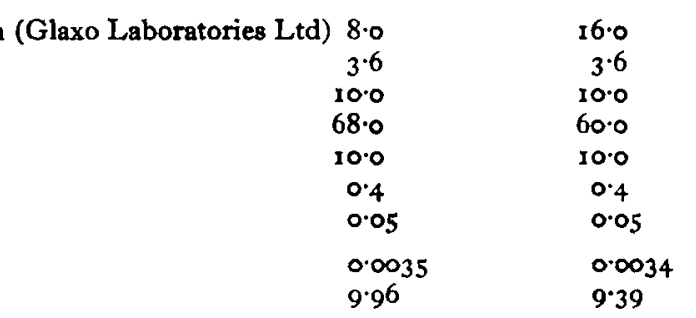

* Contained (parts): sodium chloride 22 , calcium carbonate 76 , potassium dihydrogen orthophosphate I03, tripotassium citrate (monohydrate) 125 , iron citrate (trihydrate) 5 , trace-element mixture (de Loureiro, 1931) 0.7 .

† Contained (parts): inositol 15.5, nicotinic acid ro, calcium pantothenate ro, $p$-aminobenzoic acid 7.5 , thiamine hydrochloride 3 , ribollavin 3 , pyridoxine hydrochloride 0.8 , biotin 0.05 , folic acid 0.1 , menaphthone (2-methyl-1:4-naphthaquinone) 0.05 .

\section{Analytical methods}

Diets were ashed at $550^{\circ}$ and digested with hot, about $6 \mathrm{~N}-\mathrm{HCl}$ for determination of $\mathrm{Ca}$ and $\mathrm{Mg}$. For determination of $\mathrm{P}, 10 \%(\mathrm{w} / \mathrm{v})$ sodium acetate solution was added before ashing and the ash digested with hot, about $8 \mathrm{~N}-\mathrm{HNO}_{3}$. Faeces were ashed at $55^{\circ}$ and digested with hot, about $6 \mathrm{~N}-\mathrm{HCl}$; in Expt 4 sodium acetate solution was added before ashing. The chloride concentration of these solutions of faeces was not sufficient to interfere with the $\mathrm{P}$ determinations. The combined urines and washings were evaporated to dryness, ashed at $520^{\circ}$ and digested with hot, about $3.4 \mathrm{~N}-\mathrm{HCl}$. Ca was determined by McCrudden's (1911) volumetric method and P by the molybdivanadate method (Kitson \& Mellon, 1944; Hanson, 1950). Mg was determined by the method described by Godden (1937, p. 39) with the following modifications: 


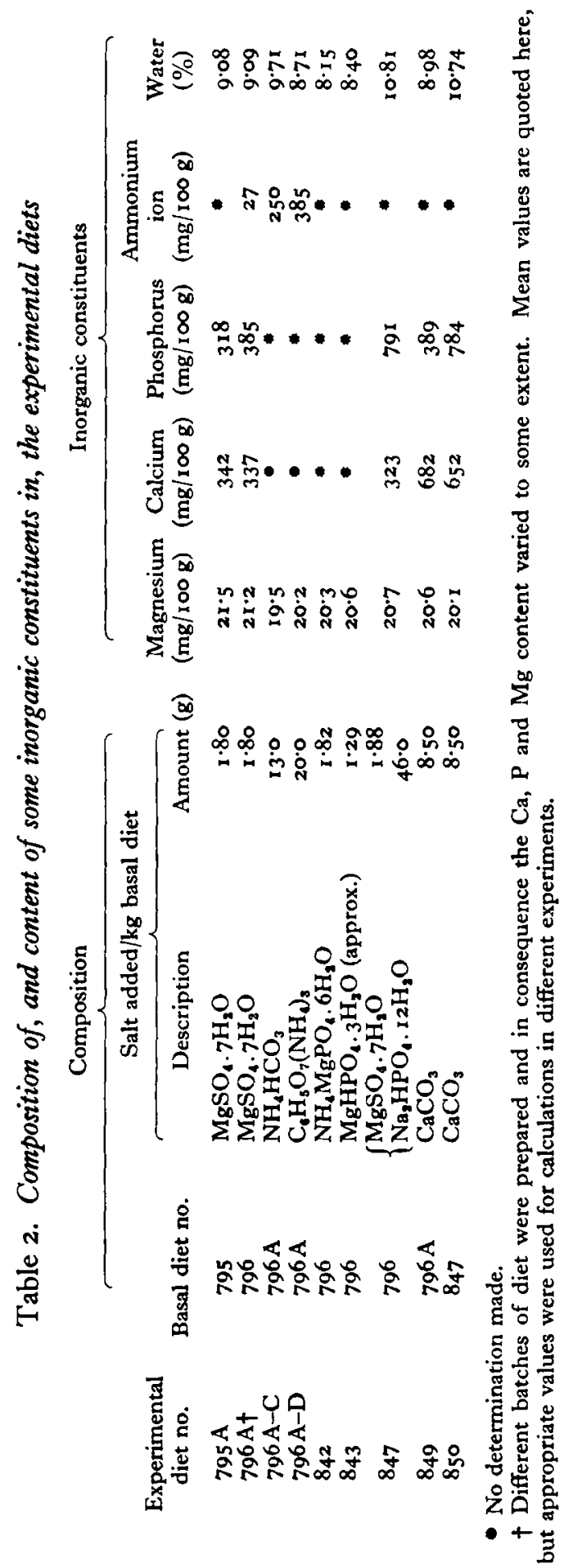


Ca was precipitated as the oxalate at $\mathrm{pH}_{4-5}{ }^{-5}$ (Smith, 1957) and the tube and precipitate were washed once with about $\mathrm{I} \mathrm{ml}$ distilled water; sodium citrate was used to prevent the co-precipitation of iron during the precipitation of the ammonium magnesium phosphate, and the $33 \%(\mathrm{v} / \mathrm{v})$ ammonia solution quoted by Godden $(1937, \mathrm{p} .40)$ for washing the $\mathrm{Mg}$ precipitate was replaced by one of $10 \%(\mathrm{v} / \mathrm{v})$ strength. Two precipitations of the $\mathrm{Mg}$ were found necessary for satisfactory results. The precipitate was finally dissolved in a small volume of about $2 \mathrm{~N}-\mathrm{HNO}_{3}$, the solution transferred to a volumetric flask and $P$ determined as above. In order to check for manganese contamination, additional ammonium magnesium phosphate precipitates were prepared from faeces in Expts $\mathrm{I}$ and 4 and from the low-Mg basal diets 795 and 796 , and $\mathrm{Mn}$ was either estimated colorimetrically by oxidation to permanganate (Godden, 1937, p. 19) or removed from the precipitate by conversion into the insoluble hydrated oxide with bromine water (Duckworth \& Godden, I938; Davidson, 1952). In all these instances $\mathrm{Mn}$ contamination was negligible, but was not checked in other $\mathrm{Mg}$ determinations. Ammonia was determined by addition of magnesium oxide to a suspension of diet in water and distillation (Association of Official Agricultural Chemists, 1955). The value for ammonium content quoted in Table 2 is the mean of determinations made on the freshly prepared diet, and on samples that had been moistened with water and left to stand overnight to simulate feeding conditions. Only very slight losses of ammonia occurred in the latter. To reduce the loss of ammonia during storage, the diets were kept in air-tight containers.

\section{Procedure}

Until they received the experimental diets, all animals had been on the laboratory stock diet (McKinlay, 195I) from weaning. In Expts I and 2, litter-mates of similar body-weight were selected directly from animals on the stock diet. In Expts 3 and 4 , litter-mates were chosen from rats that had received the experimental diets in ordinary cages for I week; by this method of selection it was hoped to have animals of a more uniform size at the beginning of the metabolic period. Collection of excreta was begun when all the animals had become accustomed to the new surroundings, and were accepting their diets and growing satisfactorily.

Expt $\mathrm{I}$. Absorption and retention of $\mathrm{Mg}$ at two levels of protein intake. Six pairs of 46-day-old litter-mates were given diets containing 8 or $16 \%$ casein (diets $795 \mathrm{~A}$ and $796 \mathrm{~A}$, Table 2) in ordinary cages for 6 days. The animals were then transferred to metabolic cages. Collection of excreta was begun I week later and continued for Io days.

Expt 2. Effect of ammonium bicarbonate (diet $796 \mathrm{~A}-\mathrm{C}$ ) and tri-ammonium citrate (diet 796 A-D) on Mg absorption. Six groups of three $142_{2}^{1}$-week-old litter-mates were given diet $796 \mathrm{~A}, 796 \mathrm{~A}-\mathrm{C}$ or $796 \mathrm{~A}-\mathrm{D}$ (Table 2 ) in the metabolic cages. Collection of faeces was begun i I days later and continued for I week.

Expt 3. Absorption of $M g$ from ammonium magnesium orthophosphate (diet 842$)$ and magnesium hydrogen orthophosphate (diet 843). To investigate the effect of ammonia without the possibly complicating effects of the acid radicals of the ammonium salts used in Expt 2, the absorption of Mg from diets 842 and 843 (Table 2) was compared. 
Litters, in excess of the number required for the metabolic period, of 8-week-old rats were transferred to diet 842 or 843 so that litter-mates were distributed between the two diets. After I week, six pairs of litter-mates of similar body-weight were selected, one litter-mate from each diet, and placed in metabolic cages. Collection of faeces was begun I week later and continued for I week.

Expt 4. Effect of calcium carbonate and sodium orthophosphate level on the absorption of $\mathrm{Mg}$. Six groups of four litter-mate rats were selected, as for Expt 3, from ro-week-old rats that had already been given the experimental diets 796A, 847 (high-P), 849 (high-Ca) or $85^{\circ}$ (high-Ca, high-P) (Table 2) for I week. They were placed in metabolic cages and collection of faeces was begun 9 days later and continued for I week.

\section{RESULTS AND DISCUSSION}

The results are given in Tables $3^{-6}$.

\section{Absorption and retention of $M g$ at two levels of protein intake}

Table 3 shows that an increase in the dietary protein at the expense of the carbohydrate increased the percentage absorption of $\mathrm{Mg}$ from $7 \mathrm{I}^{\cdot} 7$ to $73^{\cdot 8}$, but that the difference just failed to reach the $5 \%$ level of significance. Because of the much greater gain in weight of the rats in the higher-protein group during the pre-experimental period, the initial body-weights of the animals in the two groups were very different at the beginning of the metabolic period and those having more protein consumed more food and continued to gain weight more rapidly. The endogenous loss of $\mathrm{Mg}$ by these animals is not known, but if such losses were proportionately less in the higherprotein group the small difference in apparent absorption could be accounted for. McCance et al. (1942), using peptone, gelatin, gluten or egg white as supplements, found that $\mathrm{Mg}$ absorption in man was increased from 32 to $4 \mathrm{I} \%$ when the protein content of the diet was almost trebled. This difference in absorption was much greater than that now observed with rats when dietary protein was doubled (Table 3 ). The diet used by McCance et al. ( 1942 ) had as a component ' $92 \%$ wheatmeal bread' which contains phytate. The amount of bread in this diet was not mentioned, but, in view of the statement of McCance et al. (1942) that commercial 'phytin' is more soluble in solutions of $\alpha$-amino acids than in water, it is possible that the effect of protein on $\mathrm{Mg}$ absorption may be more marked with diets containing phytate.

Table 3 shows that, although the percentage of $\mathrm{Mg}$ retained by animals in the higher-protein group was significantly greater $(0.01>P>0.001)$, the quantity of $\mathrm{Mg}$ retained per unit gain in weight was slightly less $(0.05>P>0.01)$ than in those in the lower-protein group. Thus, although more $\mathrm{Mg}$ was retained by the rats in the higher-protein group, dietary $\mathrm{Mg}$ was apparently not sufficient to meet their requirements. The reduced blood $\mathrm{Mg}$ levels and increased mortality rate observed by Colby \& Frye ( $195 \mathrm{I} b)$ in rats given a diet containing $50 \%$ casein was not, however, due to a higher $\mathrm{Mg}$ requirement because of increased growth, since these animals grew less than those given the lower-protein diet. 


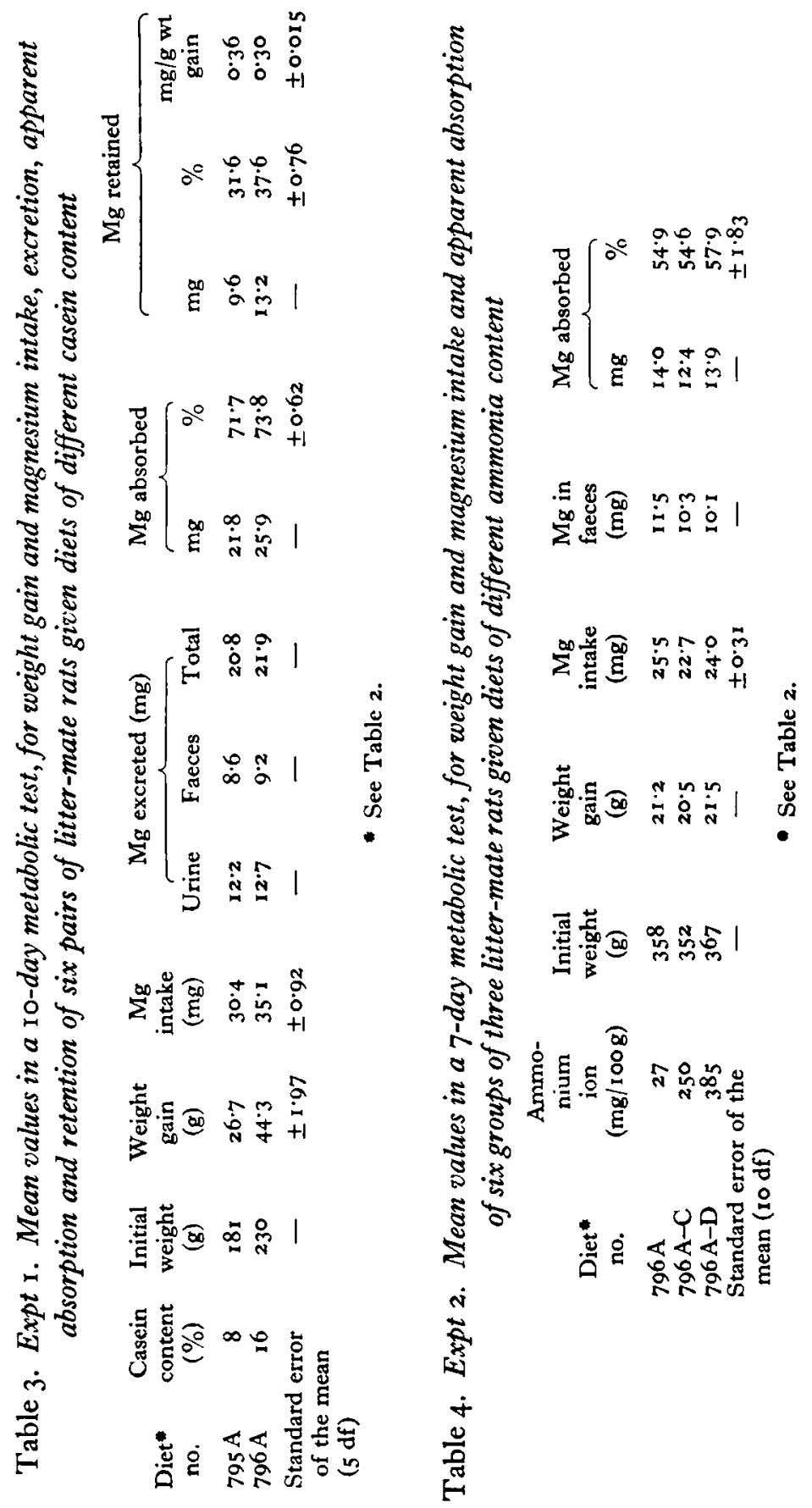




\section{Effect of the ammonium ion on $\mathrm{Mg}$ absorption}

The mechanism by which ammonia interferes with $\mathrm{Mg}$ metabolism in the ruminant is as yet unknown. It is possible that the amount of $\mathrm{Mg}$ available for absorption can be reduced by the formation of ammonium magnesium phosphate or that ammonia alters the electric potential difference between the blood and gut contents, thus affecting the passage of ions through the gut wall. The results in Table 4 show, however, that the addition to the diet of ammonium bicarbonate or tri-ammonium citrate had no significant effect $(P>0.05)$ on the apparent absorption by rats of $\mathrm{Mg}$ from the basal diet (796 A). Mg was also absorbed to the same extent from magnesium hydrogen orthophosphate and ammonium magnesium orthophosphate (Table 5). Ross (196I), using a preparation of isolated small intestine from rats, was also unable to detect any interference by ammonium chloride with the transport of $\mathrm{Mg}$.

Table 5. Expt 3. Mean values, in a 7-day metabolic test, for weight gain and magnesium intake, excretion and apparent absorption of six pairs of litter-mate rats given diets containing ammonium magnesium orthophosphate (diet 842 ) or magnesium hydrogen orthophosphate (diet 843)

\begin{tabular}{|c|c|c|c|c|c|c|}
\hline \multirow{2}{*}{$\begin{array}{c}\text { Diet } \\
\text { no. }\end{array}$} & \multirow{2}{*}{$\begin{array}{l}\text { Initial } \\
\text { weight } \\
\text { (g) }\end{array}$} & \multirow{2}{*}{$\begin{array}{c}\text { Weight } \\
\text { gain } \\
\text { (g) }\end{array}$} & \multirow{2}{*}{$\begin{array}{c}\mathrm{Mg} \\
\text { intake } \\
(\mathrm{mg})\end{array}$} & \multirow{2}{*}{$\begin{array}{l}\mathrm{Mg} \text { in } \\
\text { faeces } \\
(\mathrm{mg})\end{array}$} & \multicolumn{2}{|c|}{ Mg absorbed } \\
\hline & & & & & mg & $\% \dagger$ \\
\hline $\begin{array}{l}842 \\
843\end{array}$ & $\begin{array}{l}285 \\
286\end{array}$ & $\begin{array}{l}29 \cdot 8 \\
31 \cdot 3\end{array}$ & $\begin{array}{l}26 \cdot 2 \\
25 \cdot 1\end{array}$ & $\begin{array}{l}8 \cdot 4 \\
8 \cdot 3\end{array}$ & $\begin{array}{l}17 \cdot 8 \\
16 \cdot 8\end{array}$ & $\begin{array}{l}67 \cdot 9 \pm 2 \cdot 34 \\
66 \cdot 9 \pm 1 \cdot 66\end{array}$ \\
\hline
\end{tabular}

Effect of level of calcium carbonate and sodium orthophosphate on the absorption of $M g$

The results for the apparent absorption of $\mathrm{Mg}, \mathrm{Ca}$ and $\mathrm{P}$ from diets varying in $\mathrm{Ca}$ and phosphate content are given in Table 6 . The absorption of $\mathrm{Mg}$ was significantly reduced $(P<0.00 \mathrm{I})$ by an increase in the level of phosphate or $\mathrm{Ca}$ in the diet, and was further reduced $(0.01>P>0.001)$ when both were simultaneously increased. Increase in dietary phosphate had no significant effect on percentage absorption of $\mathrm{Ca}$ at either level of dietary $\mathrm{Ca}$. Increase in dietary $\mathrm{Ca}$ decreased significantly $(P<0.00 \mathrm{I})$ the percentage of $\mathrm{P}$ absorbed at each level of phosphate. The finding that absorption of $\mathrm{Mg}$ was reduced with increase in dietary $\mathrm{Ca}$ is in agreement with the work of Alcock \& MacIntyre (1960), and Tufts \& Greenberg (1937-8) also found that the severity of the signs of $\mathrm{Mg}$ deficiency in rats was increased when the $\mathrm{Ca}$ and $\mathrm{P}$ levels of a diet containing $5 \mathrm{mg} \mathrm{Mg} / \mathrm{ro0}, 0.87 \% \mathrm{Ca}$ and $0.80 \% \mathrm{P}$ were changed to $\mathrm{r} \cdot 16 \%$ $\mathrm{Ca}$ and $0.75 \% \mathrm{P}$. When the levels of $\mathrm{Ca}$ and $\mathrm{P}$ were $\mathrm{r} \cdot 66$ and $\mathrm{r} \cdot 00 \%$, respectively, the minimum $\mathrm{Mg}$ content of the diet necessary for normal growth was increased to about $13 \mathrm{mg} / \mathrm{roO} \mathrm{g}$ diet. However, O'Dell et al. (1960), using a diet containing $0.4 \% \mathrm{P}$ and $5 \mathrm{mg} \mathrm{Mg} / \mathrm{r} \circ 0 \mathrm{~g}$, did not find that $\mathrm{Mg}$ deficiency signs were accentuated when the $\mathrm{Ca}$ level was increased from 0.9 to $\mathrm{I} .7 \%$. The effect of increased phosphate (Table 6) was similar to that found by O'Dell et al. (1957), who reported that the absorption of $\mathrm{Mg}$ by the guinea-pig was impaired when dietary phosphate was 
substantially increased, but in contrast to their findings $\mathrm{Ca}$ absorption was not affected in the experiment described here. With rats, O'Dell et al. (I960) also found that the severity of the signs of $\mathrm{Mg}$ deficiency was increased when the level of dietary $\mathrm{P}$ was increased. No marked effect of phosphate on $\mathrm{Mg}$ absorption is apparent from the results of Meintzer \& Steenbock (1955) who gave rats a diet containing $0.12 \% \mathrm{Mg}$ and 0.14 or $0.34 \% \mathrm{P}$, but these levels of $\mathrm{P}$ were lower than those used by O'Dell et al. (1957, I960). The further reduction in $\mathrm{Mg}$ absorption when the dietary $\mathrm{Ca}$ and phosphate levels were simultaneously increased (Table 6) is of interest in connexion with the observations of O'Dell et al. (1960) that in the absence of adequate $\mathrm{Mg}$ guinea-pigs receiving a diet containing a high level of $\mathrm{Ca}$ and $\mathrm{P}$ gained less weight

Table 6. Expt 4. Mean values, in a 7-day metabolic test, for weight gain and magnesium, calcium and phosphorus intake and apparent absorption of six groups of four litter-mate rats given diets of different $\mathrm{Ca}$ and $P$ content

\begin{tabular}{|c|c|c|c|c|c|c|c|c|}
\hline \multirow{2}{*}{$\begin{array}{c}\text { Diet* } \\
\text { no. }\end{array}$} & \multirow{2}{*}{$\begin{array}{c}\mathrm{Ca} \\
(\mathrm{mg} / \\
100 \mathrm{~g})\end{array}$} & \multirow{2}{*}{$\begin{array}{c}\mathrm{P} \\
(\mathrm{mg} / \\
100 \mathrm{~g})\end{array}$} & \multirow{2}{*}{$\begin{array}{c}\text { Initial } \\
\text { weight } \\
\text { (g) }\end{array}$} & \multirow{2}{*}{$\begin{array}{c}\text { Weight } \\
\text { gain } \\
\text { (g) }\end{array}$} & \multirow{2}{*}{$\begin{array}{c}\mathrm{Mg} \\
\text { intake } \\
\text { (mg) }\end{array}$} & \multirow{2}{*}{$\begin{array}{l}\mathrm{Mg} \text { in } \\
\text { faeces } \\
\text { (mg) }\end{array}$} & \multicolumn{2}{|c|}{ Mg absorbed } \\
\hline & & & & & & & $\mathrm{mg}$ & $\%$ \\
\hline $796 \mathrm{~A}$ & 335 & 392 & 317 & $23 \cdot 2$ & $25 \cdot 8$ & $8 \cdot 6$ & $17 \cdot 2$ & $66 \cdot 7$ \\
\hline 847 & 323 & $79 \mathrm{I}$ & 310 & 23.0 & 26.5 & $14 \cdot 1$ & $12 \cdot 4$ & $46 \cdot 8$ \\
\hline 849 & 682 & 389 & 315 & $19 \cdot 3$ & $26 \cdot 9$ & $15 \cdot 3$ & $11 \cdot 6$ & $43 \cdot 1$ \\
\hline 850 & 652 & 784 & 307 & 19.5 & 24.5 & $17 \cdot 5$ & $7 \cdot 0$ & $28 \cdot 6$ \\
\hline \multicolumn{3}{|c|}{$\begin{array}{l}\text { Standard error of the } \\
\text { mean (15 df) }\end{array}$} & 一 & - & $\pm 1 \cdot 18$ & - & - & $\pm 3 \cdot 29$ \\
\hline \multirow[b]{2}{*}{$\begin{array}{l}\text { Diet* } \\
\text { no. }\end{array}$} & \multirow{2}{*}{$\begin{array}{c}\mathrm{Ca} \\
\text { intake } \\
(\mathrm{mg})\end{array}$} & \multirow{2}{*}{$\begin{array}{r}\mathrm{Ca} \text { in } \\
\text { faeces } \\
(\mathrm{mg})\end{array}$} & \multicolumn{2}{|c|}{ Ca absorbed } & \multirow{2}{*}{$\begin{array}{c}\mathbf{P} \\
\text { intake } \\
(\mathbf{m g})\end{array}$} & \multirow{2}{*}{$\begin{array}{c}P \text { in } \\
\text { faeces } \\
(\mathrm{mg})\end{array}$} & \multicolumn{2}{|c|}{ P absorbed } \\
\hline & & & $\mathrm{mg}$ & $\%$ & & & $\mathrm{mg}$ & $\%$ \\
\hline $796 \mathrm{~A}$ & 420 & I94 & 226 & $53 \cdot 8$ & 492 & 59 & 433 & $88 \cdot 0$ \\
\hline 847 & 413 & 193 & 220 & $53 \cdot 3$ & 1010 & 94 & 916 & $90 \cdot 7$ \\
\hline 849 & 893 & 657 & 236 & 26.4 & 509 & 224 & 285 & $56 \cdot 0$ \\
\hline 850 & 797 & 546 & 251 & $3 I \cdot 5$ & 959 & 254 & 705 & $73 \cdot 5$ \\
\hline \multicolumn{3}{|c|}{$\begin{array}{l}\text { Standard error of the } \\
\text { mean ( } 5 \mathrm{df} \text { ) }\end{array}$} & \pm 13.4 & $\pm 2 \cdot 13$ & - & - & \pm 29.4 & $\pm I \cdot I I$ \\
\hline
\end{tabular}

and died sooner than animals given diets containing less $\mathrm{Ca}$ and $\mathrm{P}$. Similarly, Forbes ( $196 \mathrm{I}$ ), studying the effect of two levels of dietary $\mathrm{Ca}$ and $\mathrm{P}$, found that the visible signs of $\mathrm{Mg}$ deficiency in rats were produced most readily on diets containing the higher levels of $\mathrm{Ca}$ and $\mathrm{P}$. Forbes ( $196 \mathrm{I}$ ) increased the content of $\mathrm{Ca}$ of a basal diet containing $14 \mathrm{mg} \mathrm{Mg} / 100 \mathrm{~g}$ from 0.4 to $0.8 \%$ and that of $\mathrm{P}$ from 0.2 to $0.6 \%$. Tufts \& Greenberg (1937-8), however, did not apparently observe any marked accentuation of external signs of $\mathrm{Mg}$ deficiency in rats given a diet containing only $5 \mathrm{mg} \mathrm{Mg} / \mathrm{I} 00 \mathrm{~g}$ when dietary $\mathrm{Ca}$ was increased from 0.39 to $0.87 \%$ and dietary $\mathrm{P}$ from 0.45 to $0.80 \%$.

It is evident from the results presented that dietary $\mathrm{Ca}$ and phosphate have a marked effect on the absorption of $\mathrm{Mg}$ and should be considered when assessing the adequacy of a diet with respect to $\mathrm{Mg}$. Protein (casein) appeared to have only a slight effect on $\mathrm{Mg}$ absorption at the levels studied, but by increasing the growth rate it probably increased the $\mathrm{Mg}$ requirement of the animal. 


\section{SUMMARY}

1. The effect of the dietary level of casein on the apparent absorption and retention of magnesium, and of the ammonium ion on its apparent absorption, has been studied in rats aged between 2 and 4 months. The apparent absorption of $\mathrm{Mg}$, calcium and phosphorus at two levels of dietary $\mathrm{Ca}$ and orthophosphate has also been investigated. In all the experiments the $\mathrm{Mg}$ level of the diets was about $20 \mathrm{mg} /$ $100 \mathrm{~g}$ diet.

2. An increase in dietary casein level from 8 to $16 \%$ caused a slight but insignificant increase in the apparent percentage absorption of $\mathrm{Mg}$. The gains in body-weight and the percentage of $\mathrm{Mg}$ retained by the animals given the higher-protein diet were significantly greater than those of the animals on the lower-protein diet.

3. The apparent absorption of $\mathrm{Mg}$ was not affected when the ammonium ion as ammonium bicarbonate, tri-ammonium citrate or ammonium magnesium phosphate was added to the diet.

4. The apparent absorption of $\mathrm{Mg}$ was significantly reduced by an increase in the dietary level of $\mathrm{Ca}$ from 0.34 to $0.68 \%$ or of $\mathrm{P}$ from 0.39 to $0.79 \%$ and was further reduced when $\mathrm{Ca}$ and $\mathrm{P}$ were simultaneously increased to levels of 0.65 and $0.78 \%$, respectively. The increase in dietary phosphate had no significant effect on apparent percentage absorption of $\mathrm{Ca}$ at either level of $\mathrm{Ca}$ intake, but the increase in dietary $\mathrm{Ca}$ decreased significantly the apparent percentage absorption of $\mathrm{P}$ at each level of phosphate intake.

I am grateful to Dr K. M. Henry and Dr J. A. F. Rook for advice, to Mrs M. R. Hussey for carrying out the ammonia analyses, and to Miss M. V. Chapman for help in feeding the animals.

\section{REFERENCES}

Ackroyd, H. \& Hopkins, F. G. (I916). Biochem. F. 10, 55 I.

Alcock, N. \& MacIntyre, I. (1960). Biochem. F. 76, 19 P.

Association of Official Agricultural Chemists (1955). Official Methods of Analysis, 8th ed., p. I3.

Washington, D.C. : Association of Official Agricultural Chemists.

Bunce, G. E., Chiemchaisri, Y. \& Phillips, P. H. (1962). Y. Nutr. 76, 23.

Colby, R. W. \& Frye, C. M. (1951 a). Amer. F. Physiol. 166, 209.

Colby, R. W. \& Frye, C. M. (195 I b). Amer. F. Physiol. 166, 408.

Davidson, J. (1952). Analyst, 77, 263.

De, H. N. \& Basu, K. P. (1949). Indian F. med. Res. 37, 213.

de Loureiro, J. A. (1931). Arch. Pat., Lisboa, 3, 72.

Duckworth, J. \& Godden, W. (1938), Analyst, 63, 805.

Forbes, R. M. (1961). Fed. Proc. 20, 293.

Godden, W. (editor) (1937). Tech. Commun. Bur. Anim. Nutr., Aberd., no. 9.

Hanson, W. C. (1950). F. Sci. Fd Agric. I, 172.

Head, M. J. \& Rook, J. A. F. (I955). Nature, Lond., 176, 262.

Head, M. J. \& Rook, J. A. F. (1957). Proc. Nutr. Soc. 16, 25.

Hegsted, D. M., Vitale, J. J. \& McGrath, H. (1956). F. Nutr. 58, 175.

Heller, V. G. \& Haddad, M. (1936). F. biol. Chem. rr3, 439.

Kitson, R. E. \& Mellon, M. G. (1944). Industr. Engng Chem. (Anal.), 16, 379.

Kunkel, H. O. \& Pearson, P. B. (1948). Arch. Biochem. 18, 461.

Leichsenring, J. M., Norris, L. M. \& Lamison, S. A. (1951). F. Nutr. $45,477$.

McAleese, D. M. \& Forbes, R. M. (1961). 7. Nutr. 73, 94.

McCance, R. A., Widdowson, E. M. \& Lehmann, H. (1942). Biochem. F. 36, 686.

McCrudden, F. H. (191 1). F. biol. Chem. ro, 187 . 
McKinlay, H. (1951). F. Anim. Tech. Ass. 2, no. 2, p. 2.

Malcolm, J. (1905). F. Physiol. 32, I83.

Meintzer, R. B. \& Steenbock, H. (1955). F. Nutr. 56, 285.

Nugara, D. \& Edwards, H. M. Jr. (1961). Fed. Proc. 20, 294.

O'Dell, B. L., Morris, E. R., Pickett, E. E. \& Hogan, A. G. (1957). F. Nutr. 63, 65.

O'Dell, B. L., Morris, E. R. \& Regan, W. O. (1960). F. Nutr. 70, 103.

Ross, D. B. (1961). Nature, Lond., 189, 840 .

Smith, R. H. (1957). Biochem. F. 67, 472 .

Tufts, E. V. \& Greenberg, D. M. (1937-8). F. biol. Chem. r22, 71 5. 